University of Nebraska - Lincoln

DigitalCommons@University of Nebraska - Lincoln

\title{
Invasiveness of Some Biological Control Insects and Adequacy of Their Ecological Risk Assessment and Regulation
}

\author{
Svata M. Louda \\ University of Nebraska - Lincoln, slouda1@unl.edu \\ Amy E. Arnett \\ Unity College, aarnett@unity.unity.edu \\ Tatyana A. Rand \\ University of Nebraska - Lincoln, tatyana.rand@ars.usda.gov \\ F. L. Russell \\ University of Nebraska - Lincoln, leland.russell@wichita.edu
}

Follow this and additional works at: https://digitalcommons.unl.edu/bioscifacpub

Part of the Life Sciences Commons

Louda, Svata M.; Arnett, Amy E.; Rand, Tatyana A.; and Russell, F. L., "Invasiveness of Some Biological Control Insects and Adequacy of Their Ecological Risk Assessment and Regulation" (2003). Faculty Publications in the Biological Sciences. 99.

https://digitalcommons.unl.edu/bioscifacpub/99

This Article is brought to you for free and open access by the Papers in the Biological Sciences at DigitalCommons@University of Nebraska - Lincoln. It has been accepted for inclusion in Faculty Publications in the Biological Sciences by an authorized administrator of DigitalCommons@University of Nebraska - Lincoln. 
Published in Conservation Biology 17:1 (February 2003), pp. 73-82; doi: 10.1046/j.1523-1739.2003.02020.x

Copyright $@ 2003$ Society for Conservation Biology; published by Wiley-Blackwell. Used by permission.

Submitted January 16, 2002; revised and accepted September 16, 2002; published online February 11, 2003.

\title{
Invasiveness of Some Biological Control Insects and Adequacy of Their Ecological Risk Assessment and Regulation
}

\author{
S. M. Louda, A. E. Arnett, T. A. Rand, and F. L. Russell \\ School of Biological Sciences, University of Nebraska-Lincoln, Lincoln, NE 68588, U.S.A. \\ Corresponding author - A. E. Arnett, Department of Environmental Programs, Unity College, Unity, ME 04988, U.S.A.
}

\begin{abstract}
The problem of invasive species has reignited interest in biological control as a management tool. Classical biological control involves deliberate release of exotic natural enemies into new environments in an attempt to limit the density of an invasive species. Persistent, sustained limitation of invasive species by coevolved natural enemies is a seductive concept. Evidence now suggests, however, that biological control through the release of natural enemies can carry unanticipated ecological risks. There have been ecological side effects of distributing a deliberately introduced weevil (Rhinocyllus conicus) and an adventitious weevil (Larinus planus) for the biological control of exotic thistles. Both weevils have had major direct effects on key population-growth parameters of native thistles, and $R$. conicus has had an indirect effect on the interaction between a thistle and a native insect. These findings led us to review how ecological risk is evaluated, and to ask whether pre-release tests can predict the types of ecological effects documented. We conclude that, when done thoroughly, the tests used can determine host specificity by identifying physiological host range, but the usual tests cannot be relied upon to predict the ecological host range or impact on populations of less-preferred but accepted native species. Our data provide support for suggestions that the behavioral and developmental data now taken need to be supplemented with additional data on population parameters to better predict field-host use, population growth, interaction strengths, and ecological outcomes for native species that are potential hosts.
\end{abstract}

\section{Invasividad de Algunos Insectos de Control Biológico y Adecuación de Su Evaluación de Riesgo Ecológico y Regulación}

\section{Resumen}

El problema de las especies invasoras ha despertado nuevo interés en el control biológico como una herramienta de manejo. El control biológico clásico implica la liberación deliberada de enemigos naturales exóticos en nuevos ambientes con la intención de limitar la densidad de una especie invasora. La limitación persistente, sostenida de especies invasoras por enemigos naturales coevolucionados es un concepto seductor. Sin embargo, la evidencia ahora sugiere que la liberación de enemigos naturales para el control biológico puede acarrear riesgos ecológicos no anticipados. Hubo efectos ecológicos secundarios por la introducción deliberada de un gorgojo (Rhinocyllus conicus) y de un gorgojo adventicio (Larinus planus) para el control biológico de abrojos exóticos. Ambos gorgojos han tenido importantes efectos directos sobre los parámetros clave del crecimiento poblacional de abrojos nativos, y R. conicus ha tenido un efecto indirecto en una interacción abrojo - insecto nativo. Estos hallazgos nos condujeron a revisar como se evalúa el riesgo ecológico y a preguntar si las pruebas previas a la liberación pueden predecir los tipos de efectos ecológicos documentados. Concluimos que las pruebas utilizadas, cuando están bien hechas, pueden determinar la especificidad del huésped mediante la identificación del rango fisiológico del huésped; sin embargo, las pruebas convencionales no son confiables para predecir el rango ecológico del huésped ni su impacto sobre poblaciones de especies nativas menos preferidas, pero aceptadas. Nuestros datos apoyan las sugerencias que los datos de conducta y de desarrollo actuales necesitan ser suplementados con datos adicionales referentes a los parámetros poblacionales para predecir mejor el uso de huéspedes, el crecimiento de la población, las fortaleza de la interacción y las consecuencias ecológicas en las especies nativas que son huéspedes potenciales. 


\section{Introduction}

Concern over the environmental effects of invasive exotic species has received increased attention in the last decade (Office of Technology Assessment 1993; Vitousek et al. 1996; Williamson 1996; Wilcove et al. 1998; Ewel et al. 1999; Pimentel et al. 2000). Clearly, some species, when spread by human activity and released from indigenous limiting factors, expand explosively in new environments. Examples include large, dense stands of Opuntia spp. cacti in Australian grazing lands (Dodd 1940) and Eurasian thistles (Carduus spp.) in North American pastures and rangelands (Dunn 1976). Biological control has been suggested as a longterm, cost-effective, sustainable, and environmentally sound means of invasive species control (e.g., Greathead 1995; Office of Technology Assessment 1995; MacFadyen 1998; Thomas \& Willis 1998), including in parks and natural preserves (Malecki \& Blossey 1994; Greathead 1995). Classic cases of successful biological control of weeds provide evidence that biocontrol is possible under some conditions (e.g., Dodd 1940; Huffaker \& Kennett 1959; Zimmermann et al. 1986; McEvoy et al. 1991). However, success rates have varied, from $41 \%$ of cases with some control (Office of Technology Assessment 1995) to only 20\% with complete control (Williamson \& Fitter 1996). Also, it is becoming clear that there are ecological risks associated with this strategy that remain largely unknown and unexamined (Simberloff 1981, 1992; Howarth 1990; Louda et al. 1997, 1998; Louda 1999b, 2000; Simberloff \& Stiling 1996; Stiling \& Simberloff 1999).

Biological control is a biologically based technology that is a form of environmental engineering, involving deliberate manipulation of natural systems. Classical biological control involves the release and spread of exotic natural enemies in an attempt to limit the population density of a pest species (Van Driesche \& Bellows 1996; Thomas \& Willis 1998). In the ideal case with plants, a narrowly host-specific, coevolved phytophagous insect or pathogen from the indigenous region is released into the new region and the targeted weed population declines. In the more typical case, multiple less narrowly specific natural enemies from the indigenous area are released under the assumption that, in the absence of their own natural enemies and competitors, one or more may limit the density of the invasive plant (Thomas \& Willis 1998). An implicit assumption underlying this process is that the information available prior to release is sufficient to predict and prevent significant ecological effects. Recent studies suggest that this assumption needs to be reexamined (e.g., Arnett \& Louda 2002). These studies re- port significant ecological effects on native species of insects used in the biological control of both weeds (Louda et al. 1997; Johnson \& Stiling 1998; Callaway 1999; Pearson et al. 2000; Louda \& O'Brien 2002 and insects (Boettner et al. 2000; Henneman \& Memmott 2001). Such observations suggest that the usual procedures (Harris \& McEvoy 1985; Louda \& Arnett 2000; Arnett \& Louda 2002) and present oversight of biological control (Strong \& Pemberton 2000) merit further research and improvement (McEvoy 1996; Louda 1999a, 2000; Schaffner 2001).

Here we summarize our findings on the ecological effects of two weevils, one deliberately introduced (Rhinocyllus conicus) and one adventitious (Larinus planus), that are being used for the biological control of alien thistles. In addition, we review the standard approach used to evaluate ecological risk and ask whether these data provide sufficient information to gauge the probable magnitude of ecological interaction strengths under new environmental conditions. We then discuss some of the implications of these results for future environmental risk assessment and management. We conclude that even the most rigorous development of the host-specificity data will not provide the information required to predict patterns of host use and population growth in the field, especially outside the initial habitat targeted. Direct evaluation is needed of these dimensions of ecological risk for populations of native species that are acceptable but less-preferred hosts in the host specificity tests.

\section{Rhinocyllus conicus Effects on Native Thistles in Prairie}

The flower head weevil ( $R$. conicus Fröl.) was introduced into the United States from Europe in 1969 to limit seed production by invasive Eurasian Carduus spp. (Kok \& Surles 1975; Rees 1977), especially musk or nodding thistle (C. nutans). Since introduction, this univoltine weevil has been reared from flower heads of one-third of the North American Cirsium spp. (Rees 1977; Goeden \& Ricker 1987 and references therein; Turner et al. 1987; Louda et al. 1997; Gassmann \& Louda 2001. Numbers on native Cirsium spp. in the central United States have increased over time (Louda et al. 1997). Tests of native host ranges and host specificity, evaluating adult preference and larval performance (Zwölfer \& Harris 1984), showed limited feeding by R. conicus on European Cirsium spp. and on the one North American species tested but a strong preference for Carduus nutans over most Cirsium spp. Larval development in the tests was slower and produced 
smaller adults on Cirsium spp. than on Carduus nutans. Zwölfer and Harris (1984) thus predicted selection against significant use of native North American Cirsium spp. by $R$. conicus.

Once $R$. conicus invaded our Sand Hills prairie sites in Nebraska (1993), which contain no Carduus spp., its numbers increased dramatically (Louda 1998) and negatively affected seed production of both wavyleaf thistle (Cirsium undulatum var. undulatum) and Platte thistle (C. canescens). By 1997, 33\% of wavyleaf heads at Arapaho Prairie were infested, and the proportion attacked has increased (Louda 1999b; Louda \& Arnett 2000; S.M.L., unpublished data). Also, by 1996 feeding by R. conicus reduced viable seed production by Platte thistle by $86 \%$ (Louda 1999b). Since the arrival of R. conicus, the density of Platte thistle has declined sharply (Fig. 1), with numbers of plants inversely correlated with weevil numbers (Louda \& Arnett 2000).

Experimental and observational studies done before $R$. conicus invaded the site (1976-1992) showed that native floral-feeding insects limited seed production (Lamp \& McCarty 1981, 1982; Louda et al. 1990), seedling establishment and population density (Louda et al. 1990; Louda 1994; Louda \& Potvin 1995), and ultimately lifetime fitness (Louda \& Potvin 1995). Results for wavyleaf thistle (C. undulatum) were similar (Louda 1999b; S. M. Louda, T. Tesar, \& J. Burger, unpublished data). These studies provide a quantitative baseline, making this the only case to date in which adequate pre-release data were available to allow evaluation of the direct demographic consequences of nontarget feeding by a biocontrol insect.

We also observed a significant indirect effect. The numbers of the earliest tephritid (Paracantha culta) in flower heads of Platte thistle dropped precipitously as the number of $R$. conicus increased (Louda \& Arnett 2000). We hypothesized that the addition of $R$. conicus to the flower-head guild of Platte thistle, especially in poor flowering years, caused this severe decrease (Louda et al. 1997, 1998; Louda \& Arnett 2000). Preliminary results of several experiments to test this hypothesis and to quantify the mechanisms underlying floral insect herbivore interactions (S.M.L. et al., unpublished data) suggest that $R$. conicus modified resource use and significantly reduced the numbers of flies emerging successfully from attacked Platte thistle flower heads (Fig. 2; Louda \& Arnett 2000.

\section{Larinus planus Effect on Tracy's Thistle in Colorado}

Evidence shows that $R$. conicus has had major, direct, nontarget effects on native species in prairie. Some biological control practitioners have argued that this is an isolated case (e.g., Boldt 1997), but, unfortunately, recent evidence suggests this is not so. Another case of major, nontarget effects by a thistle control agent was discovered recently. The Eurasian weevil (Larinus planus) is currently being distributed in western North America against Canada thistle (Cirsium arvense). In central Colorado, however, L. planus has more impact on a sparse native species, Tracy's thistle (Cirsium undulatum var. tracyi), than on Canada thistle (Louda \& O'Brien 2002).

Interestingly, L. planus (previously L. carlinae) was evaluated twice as a potential biological control agent for Canada thistle. In the 1960s, it was rejected for deliberate introduction based on its diet breadth in European host-specificity tests (Zwölfer et al. 1971). In 1971, however, L. planus was found in the northeastern United States, and Wheeler and Whitehead (1985) subsequently suggested that, because it was already in the U.S.A.,

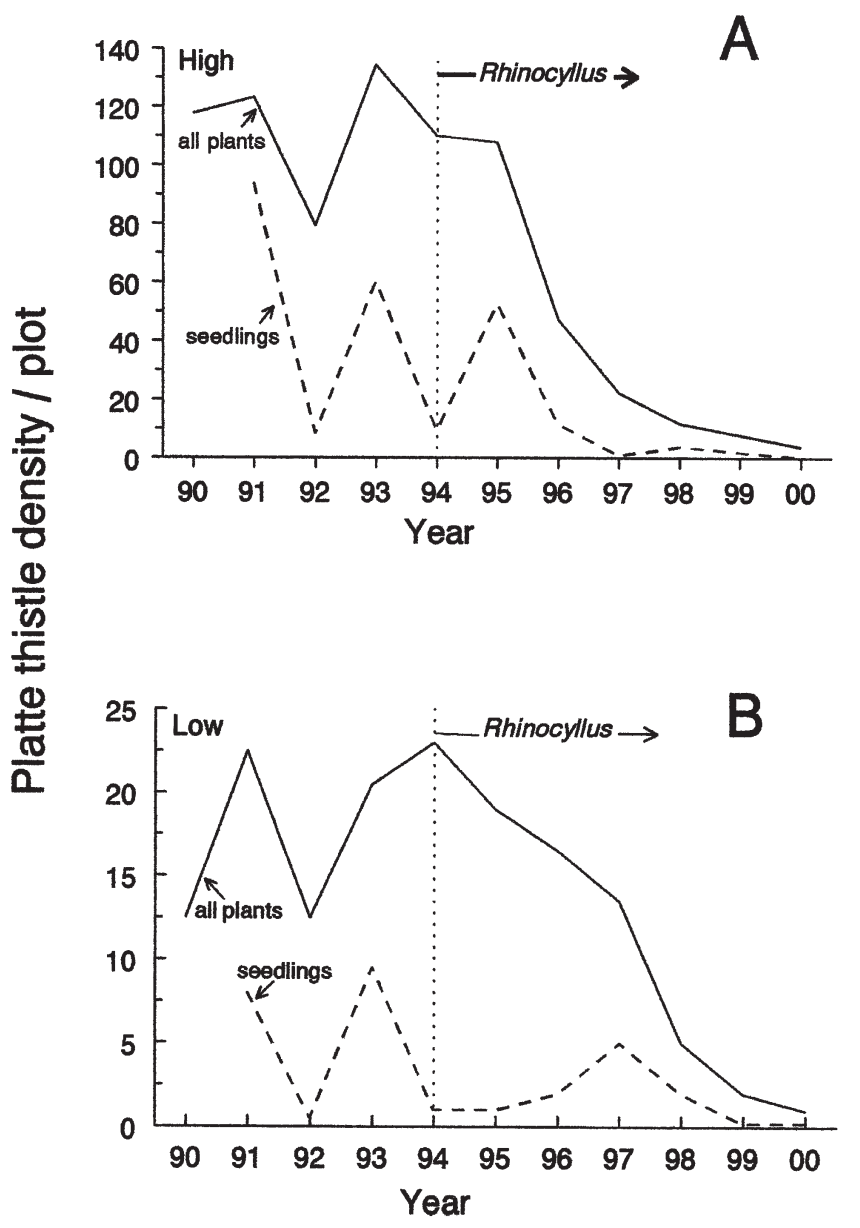

Figure 1. Population density and seedling recruitment of Platte thistle (Cirsium canescens) in $12 \times 12 \mathrm{~m}$ demography plots at Arapaho Prairie in Sand Hills Prairie, Arthur County, Nebraska, in plots with (a) high initial densities and (b) low initial densities before and after Rhinocyllus conicus invaded the site (updated from Louda \& Arnett 2000). 

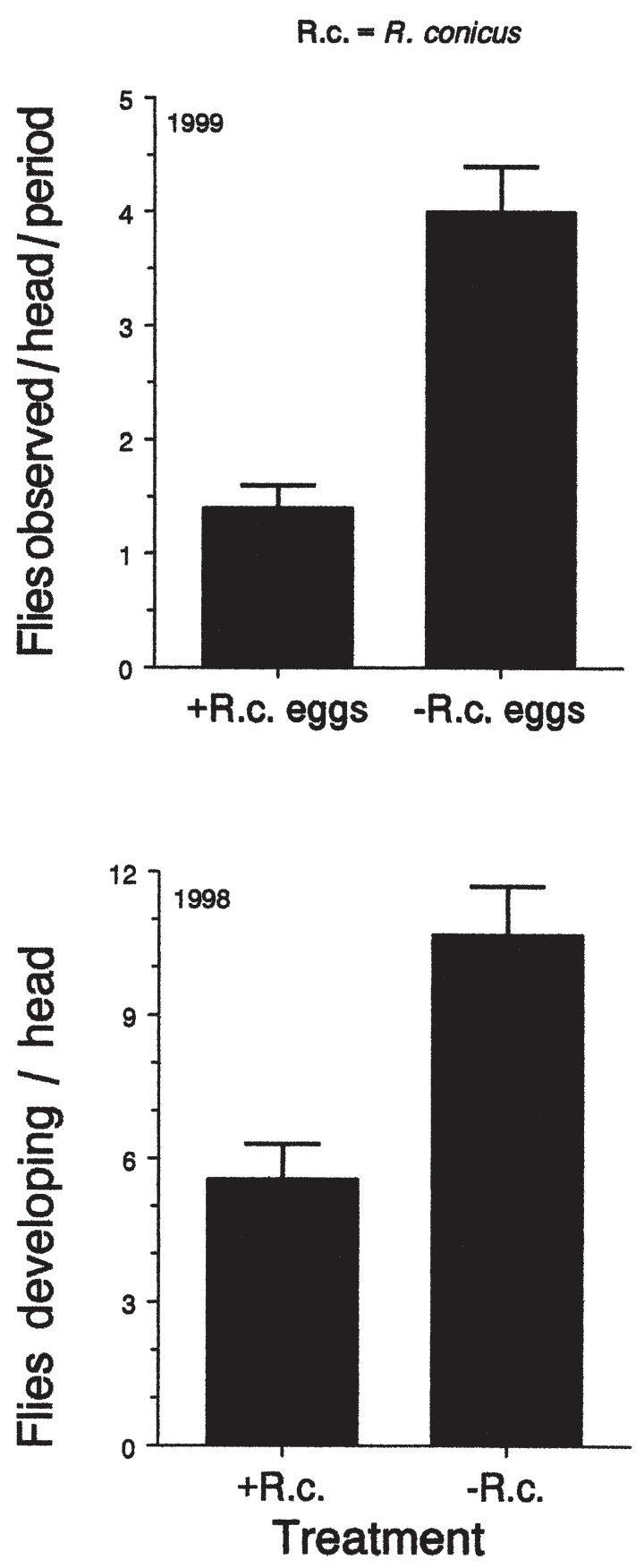

Figure 2. Effect of the exotic biological control weevil Rhinocyllus conicus on the behavior and developmental success of the native picture-winged fly (Paracantha culta) on flower heads of Platte thistle (Cirsium canescens): (a) number of flies observed in behavioral-response trials with flies given paired flower heads of Platte thistle with (+R.c. eggs) versus without (-R.c. eggs) Rhinocyllus conicus eggs on them; (b) number of adult flies emerging successfully in the field from flower heads on which $R$. conicus was allowed to oviposit (+R.c.) versus from flower heads on which $R$. conicus oviposition was prevented (-R.c.) (S.M.L. et al., unpublished data).
L. planus should be considered for redistribution to areas with Canada thistle. Consequently, McClay (1990) evaluated L. planus for use in Canada. His tests used contemporary protocols to evaluate host specificity, including evaluation of adult feeding preference, female oviposition acceptance, and larval performance on a range of potential host plant species, including five native Canadian species. In feeding "choice" tests he observed that L. planus appeared to prefer Canada thistle over the native species. In "no-choice" oviposition and larval development tests, he found that two of the three Canadian species tested were accepted for oviposition and allowed complete larval development (McClay 1990). Under the conditions of the test, however, the pupae died, and no L. planus adults emerged. In addition, the size of flower heads has been used to predict inconsequential use of North American Cirsium spp. by L. planus because their flower heads are much larger than those of its European host, Canada thistle (Zwölfer et al. 1971; McClay 1990; Harris 2002). Using his host-specificity results as a basis for predicting the ecological impact on native species that were secondary hosts, following the usual practice in biological control (MacFadyen 1998; Marohasy 1998), McClay (1990) concluded that L. planus was "unlikely to form significant populations [on native North American thistles]." This interpretation rests on the implicit assumption that environment and resource availability will not alter the outcome of ecological interactions predicted by relative preference and performance rank among accepted host species.

Since McClay's (1990) tests, L. planus has been redistributed actively into new sites in natural areas in at least five western states. For example, Louda and O'Brien (2002) found records for nine official releases of L. planus against Canada thistle in Colorado, starting in 1991. These included releases by state and federal agencies (U.S. Army, U.S. Forest Service, U.S. National Park Service) on federal lands (Fort Carson, Gunnison National Forest, Mesa Verde National Park), even though Colorado has many native Cirsium spp. (>17 spp., Harrington 1964), including two species (Cirsium ownbeyi, C. perplexans) considered rare by the Colorado Natural Heritage Program. These releases occurred after enactment of the National Environmental Policy Act (1969) and the Endangered Species Act (1972).

In central Colorado, L. planus significantly reduced seed production by the native species, Tracy's thistle C. undulatum var. tracyi (Louda \& O'Brien 2002). In 1999 , for example, $74 \%$ of the heads sampled showed evidence of L. planus, and these heads produced only 1.1 viable seeds on average, compared with 45.9 viable seeds in heads without this weevil. In 2000 feeding by L. planus occurred on $80 \%$ of Tracy's thistle plants in two sites, and $76 \%$ of the largest heads were damaged. 


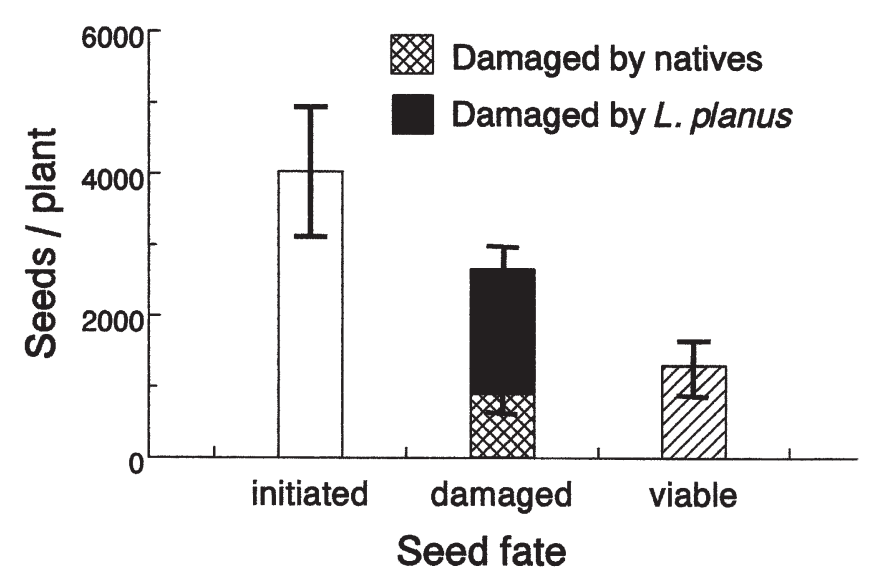

Figure 3. Reproductive effort, insect damage, and viable seed for Tracy's thistle (Cirsium undulatum var. tracyi) plants in 2000 near Gunnison, Colorado, including the impact of the flower head weevil Larinus planus used in the biological control program against Canada thistle (Cirsium arvense) (from Louda \& O'Brien 2002).

Flower heads with L. planus averaged 1.4 viable seeds, compared with 44.5 viable seeds in uninfested heads (Louda \& O'Brien 2002). Feeding by L. planus decreased the average number of viable seeds produced per plant by over $51 \%$ (Fig. 3). At the same time, L. planus had no effect on its nearby targeted exotic host, Canada thistle (C. arvense) (Louda \& O'Brien 2002). The high frequency and high level of L. planus feeding on this sparse native thistle, coupled with the lack of evidence of any effect on Canada thistle, suggest that the deliberate redistribution of this alien weevil entails a high risk-to-benefit ratio and should be stopped. These data contradict the assumption that host-specificity testing will define the host range sufficiently to fully predict subsequent ecological risk in the field.

\section{Using Testing Protocols to Define Ecological Risk}

Given what we now know about the biological control of these alien thistles, we asked what data are collected to evaluate the potential for ecological effects. Host specificity of biological control organisms, supplemented with data on host range in the indigenous region, is "one of the primary criteria used to evaluate and rank the risks that biological control organisms pose for nontarget organisms" (Blossey 1995; McEvoy 1996; MacFadyen 1998; Marohasy 1998; Thomas \& Willis 1998; Schaffner 2001). Host specificity is defined as adult feeding and oviposition preference plus success of larval development. Feeding preference is usually evaluated with "choice" tests in which insect response is measured in the presence of both the targeted exotic species and an alternative host. Oviposition acceptance and larval performance are usually evaluated with "no-choice" tests, in which only a potential alternative host is available. Larval performance on alternative potential host species is recorded and compared with growth and development on the targeted species. Potential host plants to be evaluated are chosen according to phylogenetic, economic, and sometimes conservation criteria. Ecological criteria, such as phenological synchrony, are usually not used in making this choice. A critical, implicit assumption underlying the use of this host-specificity paradigm for predicting ecological risk is that adult preference and larval performance in test environments, plus the control organism's use of species in its native region, are sufficient to predict response wherever the insect occurs in the new environment (Arnett \& Louda 2002).

Because native host range and host specificity are still the "gold standard" for prediction of ecological risk to nontarget species, it seems imperative to be explicit about what host specificity can and cannot be expected to predict. Evidence is mounting that host specificity and individual behavior can predict physiological host range as expected, but it cannot predict ecological host range and the impact on native populations under field conditions (Thomas et al. 1987; Singer et al. 1993, 1994; Arnett \& Louda 2002; Louda \& O'Brien 2002; Louda et al. 2003). For example, the relative amount of feeding among alternative host species in the field by both of the thistle biocontrol insects was not predicted based on preference and performance in host-specificity tests. Currently, $R$. conicus develops on one-third of the over 90 native North American Cirsium spp., and multiple species are experiencing large reductions in viable seed, including several rare species (Turner et al. 1987; Louda et al. 1997; Louda 1999b, 2000; Herr 2000). Also, contrary to expectations based on native host range, host specificity tests, and differences in flower head sizes, L. planus reduced seed production of a native North American thistle more than that of the targeted host (Louda \& O’Brien 2002). We conclude that host-specificity testing can identify the potential host range on an ecological time scale (Pemberton 2000; Arnett \& Louda 2002). Relative rank in preference and performance in hostspecificity tests plus native host range are not enough, however, as evidenced by these well-quantified cases of nontarget effects, to identify a priori the situations under which significant ecological effects are likely. Thus, our data and analyses strongly support suggestions that additional information on the population dynamics of interactions is needed to improve ecological risk assessment (McEvoy 1996; Hopper 2001; Schaffner 2001).

\section{Inferences for Future Risk Assessments}

Classical biological control is a deliberate alteration of community composition, with the potential to influence 
multiple ecological interactions (Strong 1997; Strong \& Pemberton 2001). Predicting the outcomes of such community rearrangement is difficult because it requires an understanding of the population consequences of the interactions for community dynamics, and knowledge of phylogenetic relationships, insect behavior, and genetic variation in host specialization (McEvoy 1996; Schaffner 2001). The cases we present here challenge the usual implicit assumption that host specificity can be extrapolated to predict ecological risk in the field for native relatives of the targeted species. Our studies, specifically, point to the need for more information on the parameters influencing the dependability of host-specificity test outcomes (e.g., Shepherd 1990); population response after dispersal into habitats without preferred host plants (Louda et al. 1997, 1998; Louda 1998, 1999b), host choice with various combinations of resource availability (F.L.R. et al., unpublished data), population resource use and growth under a range of environmental conditions, including variation in the phenology of potential resources (Louda 1998; Louda \& O'Brien 2002), and quantitative effects of interactions within guilds on possible nontarget hosts (Louda \& Arnett 2000).

\section{Ecological Evidence}

Retrospective analysis of the evidence on the interactions of R. conicus and L. planus with native Cirsium spp. in the United States reveals at least four ecological relationships that lead to suggestions for improving current testing to better predict risk to related nontarget species via direct effects, and to dependent organisms via indirect effects. These suggestions revolve around the discovery of the roles played in species interactions and ecological risk, in our cases by (1) the ecological similarity of affected species among potential host plants, including phenological synchrony of critical life-history stages between insect and affected host plants; (2) the processes affecting densities of insects and limiting population densities of the native host plants; (3) the overlap of niches within the targeted feeding guild; and (4) the limited oversight of the redistribution of insects once in the United States.

First, the evidence available suggests that native relatives of targeted species are most vulnerable to nontarget feeding (Pemberton 2000). In addition, our case histories suggest that increased use of field-related ecological criteria in the selection of species to be used in host-specificity tests would help identify the more vulnerable natives among phylogenetically related species and would lead to better quantification of potential nontarget effects. Phenology, life history, and feeding-guild structure helped explain the quantitative impacts we documented, yet these traits are generally not used to help identify species to be tested as hosts among related native plants.

Second, the results of host-specificity tests that suggest a native species may be accepted need to be fol- lowed up with additional studies if release continues to be considered an option (McEvoy 1996; Louda et al. 1998; Louda 1999a, 2000; Schaffner 2001). The standard tests now used can identify physiological host range and potential nontarget species when done comprehensively (Pemberton 1986, 2000). If these tests indicate some acceptance of nontarget native plants, however, then further tests are required to estimate how much feeding is likely in the field. Individual preference and developmental suitability rank cannot be expected to predict the response of an insect population, given the variation observed in host abundance, host phenology, and environmental conditions in nature. The $R$. conicus case clearly documents the fact that host-plant preference is irrelevant if the insect disperses into a habitat without its preferred species. It also demonstrates that information on population growth under no-choice circumstances (in the absence of the preferred species) is needed to anticipate the impact. Additionally, the L. planus case shows that host-plant preferences may be overridden in the field-for example, by relative flowering phenology. Field trials in the native region have been suggested (Marohasy 1998; Harris 2002), but the reliability of extrapolating the results of such tests to new environments and resource combinations remains unknown.

Third, the data from these studies also suggest that the relationship between feeding preference and actual levels of herbivory on alternative host plants in the field is more complex than implied by the host-range and host-specificity paradigms. Environmental context clearly influenced host choice and level of use in the field in both our cases. Preference per se among acceptable hosts under test conditions indicated little about ecological risk to the less-preferred native species under field conditions. Risk will be minimized in the absence of any evidence of potential host use (Strong \& Pemberton 2000, 2001). At the least, the pre-release data on native species related to the targeted species should include information on which native species are ecologically vulnerable to nontarget feeding and under what environmental conditions population growth on them is feasible. Our studies strongly suggest that if populations of potential nontarget species are limited by their consumers under normal conditions, then the addition of another consumer has a high probability of having a significant effect on those populations and on their interactions in the community.

Fourth, our cases clearly demonstrate a need to evaluate population and guild data on the interactions of biological control agents with nontarget species identified through host-specificity testing. To quantify actual ecological range, it will be necessary to evaluate parameters influencing the population growth of vulnerable nontarget native species and to quantify interaction effects on these parameters under a range of realistic environmental scenarios. The key question is whether there is evidence 
that the attempt to control an invasive species with the deliberate release of an exotic species has a high probability of success and a low probability of ecological harm. The modeling of population dynamics and interactions represents an initial strategy to address this question, because it ties quantitative test data, field observations, and assumptions about interactions together into a predictive analysis (e.g., Murdoch et al. 1985; Murdoch 1990; Elkinton et al. 1992; Van Driesche et al. 1994; Second \& Kareiva 1996; Murdoch \& Briggs 1996; Shea \& Kelly 1998). Such models require quantitative information on the factors limiting the exotic plant population where it is not a problem (e.g., Fowler et al. 1996, 2001; Sheppard \& Woodburn 1996) and better quantification of the dynamics of the potential nontarget species, their dependent native guilds, and their main interactions.

\section{Tradeoffs of Exotic-Species Release}

It has been argued that the risk to a native species or two, especially noncharismatic wildland plants, is outweighed by the potential benefits gained from the release of the exotic species (e.g., Blossey et al. 1994). Although evaluations of such tradeoffs are a part of the decision-making process in risk analysis, adequate analysis and identification of rational tradeoffs depend on sufficient information. The manipulation of natural systems for pest control should be based on strong quantitative evidence and reliance on as complete a database as possible. Currently, risk assessment in biological control generally relies on (1) qualitative estimates of the pest problem, (2) estimates of host range based on observations in the native region and on host-specificity tests, and (3) expert opinion on the ecological risks suggested by host-range and host-specificity tests (Louda et al. 1998; Thomas \& Willis 1998; Schaffner 2001). In addition, current policy relies on the assumption that steps 2 and 3 generally identify relevant ecological risks even with insect dispersal or redistribution across ecosystems after arrival in the United States. Little information has been gathered on the population dynamics of potential interactions (Louda 1999a, 1999b) or on potential foodweb interactions (Strong \& Pemberton 2001). Additionally, no further evidence or tests are required for permits to move insects among geographic regions. Thus, we conclude that in most cases the information required to estimate actual ecological effects and environmental risk for populations of native relatives of targeted species across multiple ecosystems is not available.

Several factors appear to contribute to this gap in information. First, perception of threat sometimes drives application of a remedy before the problem is well quantified and the causal factors understood. This often appears to be the response to exotic plants. Given the increasing evidence that there are potentially major ecological risks in releasing exotic biocontrol agents, a con- servation perspective argues for more caution and for rigorous quantitative evaluation of both benefits and potential costs among options. A thorough cost-benefit analysis requires that the invasive species threat and its causes are well documented and understood. Such analysis should include a quantitative assessment of the scale of the invasive weed problem, the factors contributing to the problem, and the environmental effects of the invasive species. Many exotic plants exist in natural systems with no apparent negative ecological effects (Williamson \& Fitter 1996; Gordon \& Thomas 1997). Thus, adequate documentation of an invasive species threat entails more than evidence of localized, dense stands of an undesired species and ballpark estimates of economic and environmental impacts. Rough estimates are inaccurate and can be misleading; ultimately, they are useless for invasive species management (Louda et al. 1998; Louda 1999a). Potential environmental impacts that need to be considered include alteration of ecosystem processes (Gordon 1997), reduction of diversity in the invaded community (Vitousek et al. 1996), and effects on populations in the interconnected, dependent food web (Louda et al. 1997; Strong 1997; Louda \& Rand 2002). Protocols need to be developed to assess these components of ecological risk.

Second, the need to know whether a potential biological control agent is likely to limit a pest population seems fundamental, but calls for such information are relatively recent (McEvoy 1996; Louda et al. 1998; McEvoy \& Coombs 1999; Callaway et al. 1999; Louda 1999a, $1999 b, 2000)$. A better understanding of the stages or processes limiting population growth of a targeted weed in its indigenous region, and how this varies under different environment conditions, for example, would contribute to predictions of the likely success of a control program. Yet such information is not regularly sought in the process of making decisions about whether or not to release an exotic biocontrol agent.

Third, the difficulty of accurately predicting the outcome of introducing an exotic species into a new community has been underestimated. The conceptual model underlying most biological control projects has been a linear food chain (Strong 1997), and the effects of trophic interconnections generally have not been evaluated (Strong \& Pemberton 2001). The accumulating field evidence now jeopardizes the implicit assumption that host-specificity data can be used to estimate ecological interaction strength for less-preferred native species in such complex contexts. The importance of considering how other species interact with the target weed, its native relatives, and other interconnected species has been illustrated by recent studies (Callaway et al. 1999; Louda 1999b; Louda \& Arnett 2000; Pearson et al. 2000).

Fourth, both cases, but especially the L. planus case, highlight a problem in the current practice of biological control: the wide availability of biological control insects 
with minimal oversight and regulation of redistribution of these organisms once they are in the United States. Many insects, including both R. conicus and L. planus, have been sold over the Internet. Current regulations aim to restrict movement among states only after evidence of harm already exists (T. Horner, personal communication), and no distinction is required between adventitious versus deliberately introduced and generally better-evaluated species. Combined with oversimplified advocacy, for example, in statements such as "Only the 'biocontrol' agents that have run the gauntlet of USDA tests and demonstrated they will starve rather than eat anything but their weedy host are released in the U.S." (2002 publicity of the Weed Control Board, Stevens County, Washington), these factors create the potential for further problems.

Thus, although the prediction of community interactions is complex, actual ecological risk cannot be evaluated without it. Adding species to ecosystems can have complicated consequences, so caution argues that these additions be better explored before a decision is made to release a biological control agent. Analysis of interaction strengths and outcomes is a rapidly evolving area of ecological research (Paine 1992; Schoener 1993; Wootton 1994), so new field and modeling techniques are being developed that could be applied. Furthermore, few release programs have included long-term quantitative monitoring to document both the effectiveness of limiting the targeted pest population and ecological interactions of the deliberately released insect within the native community. Such monitoring needs to become standard practice. The recent studies that have emerged from ecological analyses of the interactions between biological control agents and native species (e.g., Louda et al. 1997; Callaway et al. 1999; Louda 1999b; Boettner et al. 2000; Louda \& Arnett 2000; Pearson et al. 2000; Henneman \& Memmott 2001; Louda \& O'Brien 2002) are both enlightening and frightening because all suggest that ecological effects may be much more extensive and complicated than suspected.

Finally, in light of the ecological risks documented, even if the threat of a given invasive species is well quantified and population-level analyses suggest that biocontrol could effectively limit population growth without obvious ecological impacts, we suggest that alternative, less-permanent remedies still merit intensive simultaneous evaluation. Biological organisms and populations are dynamic, dispersing and evolving entities, and the durability of exotic species introductions is legendary. "Recall" of problematic species from ecosystems where they are damaging native species is either impossible or prohibitively expensive. Although some argue against increasing the length or complexity of the screening process, the irreversibility of deliberate introduction or distribution into new areas argues for, at a minimum, a policy of "first do no harm." Because multiple tactics are available to manage invasive plant species in the short term, taking the time to determine the ecological risks of biocontrol precisely, to investigate control options carefully, and to encourage open debate on benefits versus costs is feasible and prudent.

\section{Acknowledgments}

We thank the many conscientious and cheerful research students, critical colleagues, interested friends, and supportive family members that contributed to the projects summarized. Funding for the work was provided by the National Science Foundation (DEB 9221065, DEB9616210), the Katherine Ordway and Rodney Johnson Stewardship Funds of The Nature Conservancy, and the University of Nebraska Research Council.

\section{Literature Cited}

Arnett, A. E., and S. M. Louda. 2002. Re-test of Rhinocyllus conicus host specificity, and the prediction of ecological risk in biological control. Biological Conservation 106: 251-257.

Blossey, B. 1995. Host specificity screening of insect biological weed control agents as part of an environmental risk assessment. Pages 84-89 in H. M. T. Hokkanen and J. M. Lynch, editors. Biological control: benefits and risks. Cambridge University Press, Cambridge, United Kingdom.

Blossey, B., D. Schroeder, S. D. Hight, and R. A. Malecki. 1994. Host specificity and environmental impact of the weevil Hylobius transversovittatus, a biological control agent of purple loosestrife (Lythrum salicaria). Weed Science 42: 128-133.

Boettner, G. H., J. S. Elkinton, and C. J. Boettner. 2000. Effects of a biological control introduction on three nontarget native species of saturniid moths. Conservation Biology 14: 1798-1806.

Boldt, P. E. 1997. Response of a Rhinocyllus researcher. Biocontrol News and Information 18: 100N.

Callaway, R. M., T. H. DeLuca, and W. M. Belliveau. 1999. Biologicalcontrol herbivores may increase competitive ability of the noxious weed Centaurea maculosa. Ecology 80: 1196-1201.

Dodd, A. P. 1940. The biological campaign against prickly pear. Commonwealth Prickly Pear Board, Brisbane, Australia.

Dunn, P. H. 1976. Distribution of Carduus nutans, C. acanthoides, C. pycnocephalus, and C. crispus, in the United States. Weed Science 24 518-524.

Elkinton, J. S., J. P. Buonaccorsi, T. S. Bellows, and R. G. Van Driesche 1992. Marginal attack rate, k-values and density dependence in the analysis of contemporaneous mortality factors. Researches in Population Ecology 34: 29-44.

Ewel, J. J., et al. 1999. Deliberate introductions of species: research needs. BioScience 49: 619-630.

Fowler, S. V., H. M. Harman, J. Memmott, Q. Paynter, R. Shaw, A. W. Sheppard, and P. Syrett. 1996. Comparing the population dynamics of broom, Cytisus scoparius, as a native plant in the United Kingdom and France and as an invasive alien weed in Australia and New Zealand. Pages 19-26 in V. C. Moran and J. H. Hoffmann, editors. Proceedings of the ninth international symposium on the biological control of weeds. University of Cape Town, Cape Town, South Africa.

Fowler, S. V., J. Memmott, Q. E. Paynter, A. W. Sheppard, and P. Syrett. 2001. The scope and value of extensive ecological studies in 
the broom biological control programme. Pages 229-248 in E. Wajnberg, J. K. Scott, and P. C. Quimby, editors. Evaluating indirect ecological effects of biological control. CABI Publishing, CABI International, Wallingford, Oxon, United Kingdom.

Gassmann, A., and S. M. Louda. 2001. Rhinocyllus conicus: initial evaluation and subsequent ecological impacts in North America. Pages 147-183 in E. Wajnberg, J. K. Scott, and P. C. Quimby, editors. Evaluating indirect ecological effects of biological control. CABI Publishing, CABI International, Wallingford, Oxon, United Kingdom.

Goeden, R. D., and D. W. Ricker. 1987. Phytophagous insect faunas of native Cirsium thistles, C. mohavense, C. neomexicanum, and C. nidulum, in the Mojave Desert of southern California. Annals of the Entomological Society of America 80: 161-175.

Gordon, D. R. 1997. Effects of invasive, non-indigenous plant species on ecosystem processes: lessons from Florida. Ecological Applications 8: 975-989.

Gordon, D. R., and K. P. Thomas. 1997. Florida's invasion by nonindigenous plants: history, screening, and regulation. Pages 21-37 in D. Simberloff, D. C. Schmitz, and T. C. Brown, editors. Strangers in paradise: impact and management of nonindigenous species in Florida. Island Press, Washington, D.C.

Greathead, D. J. 1995. Benefits and risks of classical biological control. Pages 53-63 in H. M. T. Hokkanen and J. M. Lynch, editors. Biological control: benefits and risks. Cambridge University Press, Cambridge, United Kingdom.

Harrington, H. D. 1964. Manual of the plants of Colorado. Sage Books, Denver, $\mathrm{CO}$.

Harris, P. 2002. Host specificity in weed biocontrol. Lethbridge Research Centre, Canada. Available from http://0-res2.agr.gc.ca.library.unl.edu/Lethbridge/weedbio/hostspec.htm (accessed June 2002).

Harris, P., and P. McEvoy. 1985. The predictability of insect host plant utilization from feeding tests and suggested improvements for screening weed biological control agents. Pages 125-131 in Proceedings of the eighth international symposium on the biological control of weeds. Commonwealth Scientific, Industrial, and Research Organization, Melbourne, Australia.

Henneman, M. L., and J. Memmott. 2001. Infiltration of a Hawaiian community by introduced biological control agents. Science 293: 1314-1316.

Herr, J. C. 2000. Evaluating non-target effects: the thistle story. Pages 12-17 in M. S. Hoddle, editor. Proceedings of the California conference on biological control II. University of California, Riverside.

Hopper, K. R. 2001. Research needs concerning non-target impacts of biological control introductions. Pages 39-56 in E. Wajnberg., J. K. Scott, and P. C. Quimbey, editors. Evaluating indirect ecological effects of biological control. CABI Publishing, Oxon, United Kingdom.

Howarth, F. G. 1990. Hawaiian terrestrial arthropods: An overview. Bishop Museum Occasional Papers 30: 4-26.

Huffaker, C. B., and C. E. Kennett. 1959. A ten-year study of vegetational changes associated with biological control of Klamath weed. Journal of Range Management 12: 69-82.

Johnson, D. M., and P. D. Stiling. 1998. Distribution and dispersal of Cactoblastis cactorum (Lepidoptera: Pyralidae), an exotic Opuntiafeeding moth, in Florida. Florida Entomologist 81: 12-22.

Kok, L. T., and W. W. Surles. 1975. Successful biocontrol of Musk thistle by an introduced weevil, Rhinocyllus conicus. Environmental Entomology 4: 1025-1027.

Lamp, W. O., and M. K. McCarty. 1981. Biology and ecology of Platte thistle (Cirsium canescens). Weed Science 29: 686-692.

Lamp, W. O., and M. K. McCarty. 1982. Predispersal seed predation of a native thistle, Cirsium canescens. Environmental Entomology 11: 847-851.

Louda, S. M. 1994. Experimental evidence for insect impact on populations of short-lived, perennial plants, and its application in restoration ecology. Pages 118-138 in M. L. Bowles and C. J. Whelan, editors. Restoration of endangered species. Cambridge University Press, Cambridge, United Kingdom.
Louda, S. M. 1998. Population growth of Rhinocyllus conicus (Coleoptera: Curculionidae) on two species of native thistles in prairie. Environmental Entomology 27: 834-841.

Louda, S. M. 1999a. Ecology of interactions needed in biological control practice and policy. Bulletin of the British Ecological Society 29: 8-11.

Louda, S. M. 1999b. Negative ecological effects of the musk thistle biocontrol agent, Rhinocyllus conicus Fröl. Pages 215-243 in P. A. Follet and J. J. Duan, editors. Nontarget effects of biological control. Kluwer Academic Publishers, Dordrecht, The Netherlands.

Louda, S. M. 2000. Rhinocyllus conicus: insights to improve predictability and minimize risk of biological control of weeds. Pages 187193 in N. R. Spencer, editor. Proceedings of the tenth international symposium on the biological control of weeds. Agricultural Research Service, U.S. Department of Agriculture, Bozeman, Montana.

Louda, S. M., and A. E. Arnett. 2000. Predicting non-target ecological effects of biological control agents: evidence from Rhinocyllus conicus. Pages 551-567 in N. R. Spencer, editor. Proceedings of the tenth international symposium on the biological control of weeds. Agricultural Research Service, Department of Agriculture, Bozeman, Montana

Louda, S. M., and C. W. O'Brien. 2002. Unexpected ecological effects of distributing the exotic weevil Larinus planus (F.) for the biological control of Canada thistle. Conservation Biology 16: 717-727.

Louda, S. M., and M. A. Potvin. 1995. Effect of inflorescence-feeding insects in the demography and lifetime fitness of a native plant. Ecology 76: 229-245.

Louda, S. M., and T. A. Rand. 2002. Native thistles: expendable or integral to ecosystem resistance to invasion? In S. A. Levin and P. Kareiva, editors. The importance of species: perspectives on expendability and triage. Princeton University Press, Princeton, New Jersey, in press.

Louda, S. M., M. A. Potvin, and S. K. Collinge. 1990. Predispersal seed predation, postdispersal seed predation and competition in the recruitment of seedlings of a native thistle in sandhills prairie. American Midland Naturalist 124: 105-113.

Louda, S. M., D. Kendall, J. Connor, and D. Simberloff. 1997. Ecological effects of an insect introduced for the biological control of weeds. Science 277: 1088-1090.

Louda, S. M., D. Simberloff, G. Boettner, J. Connor, D. Kendall, and A. E. Arnett. 1998. Insights from data on the nontarget effects of the flowerhead weevil. Biocontrol News and Information 19: $70 \mathrm{~N}-71 \mathrm{~N}$

Louda, S. M., R. W. Pemberton, M. T. Johnson, and P. A. Follett. 2003. Non-target effects: the Achilles' heel of biological control? Retrospective analyses to reduce risk associated with biocontrol introductions. Annual Review of Entomology 48, in press.

MacFadyen, R. E. 1998. Biological control of weeds. Annual Review of Entomology 43: 369-393.

Malecki, R., and B. Blossey. 1994. Insect biological weed control: an important and underutilized management tool for maintaining native plant communities threatened by exotic plant introductions. Transactions of the North American Wildlife and Natural Resource Conference 54: 400-404.

Marohasy, J. 1998. The design and interpretation of host-specificity tests for weed biological control with particular reference to insect behavior. Biocontrol News and Information 19: 13N-20N.

McClay, A. S. 1990. The potential of Larinus planus (Coleoptera: Curculionidae), an accidentally-introduced insect in North America, for biological control of Cirsium arvense. Pages 173-179 in E. S. Delfosse, editor. Proceedings of the seventh international symposium on the biological control of weeds. Instituto Sperimentale per la Patologia Vegetale, Rome.

McEvoy, P. B. 1996. Host specificity and biological pest control. BioScience 46: 401-405.

McEvoy, P. B., and E. M. Coombs. 1999. A parsimonious approach to biological control of plant invaders. Ecological Applications 9: 387-401. 
McEvoy, P. B., C. Cox, and E. Coombs. 1991. Successful biological control of ragwort, Senecio jacobaea, by introduced insects in Oregon. Ecological Applications 1: 430-442.

Murdoch, W. W. 1990. The relevance of pest-enemy models to biological control. Pages 1-24 in M. Mackauer, L. E. Ehler, and J. Roland, editors. Critical issues in biological control. Intercept, Andover United Kingdom.

Murdoch, W. W., and C. J. Briggs. 1996. Theory for biological control: recent developments. Ecology 77: 2001-2013.

Murdoch, W. W., J. Chesson, and P. L. Chesson. 1985. Biological control in theory and practice. The American Naturalist 125: 344-366.

Office of Technology Assessment 1993. Harmful non-indigenous species in the United States. OTA-F-565. U.S. Government Printing Office, Washington, D.C.

Office of Technology Assessment 1995. Biologically based technologies for pest control. OTA-ENV-636. U.S. Government Printing Office, Washington, D.C.

Paine, R. T. 1992. Food web analysis through field measurement of per capita interaction strength. Nature (London) 355: 73-75.

Pearson, D. E., K. S. McKelvey, and L. F. Ruggiero. 2000. Non-target effects of an introduced biological control agent on deer mouse ecology. Oecologia 122: 121-128.

Pemberton, R. W. 1986. Native plant considerations in the biological control of leafy spurge. Pages 365-390 in E. S. Delfosse, editor. Proceedings of the sixth international symposium on biological control of weeds. Agriculture Canada, Vancouver, British Columbia.

Pemberton, R. W. 2000. Predictable risk to native plants in weed biological control. Oecologia (Berlin):489-494.

Pimentel, D., L. Lach, R. Zuniga, and D. Morrison. 2000. Environmental and economic costs of nonindigenous species in the United States. BioScience 50: 53-64.

Rees, N. E. 1977. Impact of Rhinocyllus conicus on thistles in southwestern Montana. Environmental Entomology 6: 839-842.

Schaffner, U. 2001. Host range testing of insects for biological weed control: how can it be better interpreted? BioScience 51: 951-959.

Schoener, T. W. 1993. On the relative importance of direct versus indirect effects in ecological communities. Pages 365-411 in H. Kawanabe, J. E. Cohen and K. Iwasaki, editors. Mutualism and community organization: behavioral, theoretical, and food-web approaches. Oxford University Press, New York.

Second, D., and P. Kareiva. 1996. Perils and pitfalls in the host specificity paradigm. BioScience 46: 448-453.

Shea, K., and D. Kelly. 1998. Estimating biocontrol agent impact with matrix models: Carduus nutans in New Zealand. Ecological Applications 8: 824-832.

Shepherd, R. C. H. 1990. Problems which arise with host-specificity testing of insects. Pages 85-92 in E. S. Delfosse, editor. Proceedings of the seventh international symposium on the biological control of weeds. Insituto Sperimentale per la Patologia vegetale, Rome.

Sheppard, A. W., and T. Woodburn. 1996. Population regulation in insects used to control thistles: can this predict effectiveness? Pages 277-290 in R. B. Floyd, A. W. Sheppard and P. J. De Barro, editors. Frontiers of population ecology. Commonwealth Scientific, Industrial, and Research Organization, Melbourne.

Simberloff, D. 1981. Community effects of introduced species. Pages 53-81 in T. H. Nitecki, editor. Biotic crises in ecological and evolutionary time. Academic Press, New York.

Simberloff, D. 1992. Conservation of pristine habitats and unintended effects of biological control. Pages 103-117 in W. C. Kauffman and J. E. Nechols, editors. Selection criteria and ecological consequences of importing natural enemies. Entomological Society of America, Lanham, Maryland.

Simberloff, D., and P. Stiling. 1996. How risky is biological control? Ecology 77: 1965-1974.

Singer, M. C., C. D. Thomas, and C. Parmesan. 1993. Rapid human-induced evolution of insect-host associations. Nature (London) 366: 681-683.
Singer, M. C., C. D. Thomas, H. L. Billington, and C. Parmesan. 1994. Correlates of speed of evolution of host preference in a set of twelve populations of the butterfly Euphydryas editha. EcoScience 1: 107-114.

Stiling, P., and D. Simberloff. 1999. The frequency and strength of nontarget effects of invertebrate biological control agents of plant pests and weeds. Pages 31-43 in P. A. Follett and J. J. Duan, editors. Nontarget effects of biological control. Kluwer Academic Publishers, Boston.

Strong, D. R. 1997. Fear no weevil? Science 277: 1058-1059.

Strong, D. R., and R. W. Pemberton. 2000. Biological control of invading species: risk and reform. Science 288: 1969-1970.

Strong, D. R., and R. W. Pemberton. 2001. Food webs, risks of alien enemies and reform of biological control. Pages 229-248 in E. Wajnberg, J. K. Scott and P. C. Quimby, editors. Evaluating indirect ecological effects of biological control. CABI Publishing, CABI International, Wallingford, Oxon, United Kingdom.

Thomas, C. D., D. Ng, M. C. Singer, J. L. B. Mallet, C. Parmesan, and H. L. Billington. 1987. Incorporation of a European weed into the diet of a North American herbivore. Evolution 41: 892-901.

Thomas, M. B., and A. J. Willis. 1998. Biocontrol: risky but necessary? Trends in Ecology \& Evolution 13: 325-329.

Turner, C. E., R. W. Pemberton, and S. S. Rosenthal. 1987. Host utilization of native Cirsium thistles (Asteraceae) by the introduced weevil Rhinocyllus conicus (Coleoptera: Curculionidae) in California. Environmental Entomology 16: 111-115.

Van Driesche, R., and T. S. Bellows. 1996. Biological control. Chapman $\&$ Hall, New York.

Van Driesche, R. G., J. S. Elkinton, and T. S. Bellows. 1994. Potential use of life tables to evaluate the impact of parasitism on population growth of Phyllonorycter crataegella (Lepidoptera: Gracillariidae). Pages 37-51 in C. Maeir, editor. Integrated management of tentiform leafminers, Phyllonorycter ssp. (Lepidoptera: Gracillariidae), in North America apple orchards. Thomas Say Publications in Entomology, Entomological Society of America, Lanham, Maryland.

Vitousek, P. M., C. M. D'Antonio, L. L. Loope, and R. Westbrooks. 1996. Biological invasions as global environmental change. American Scientist 84: 468-478.

Wheeler, A. G., and D. R. Whitehead. 1985. Larinus planus (F.) in North America (Coleoptera: Curculionidae: Cleoninae) and comments on biological control of Canada thistle. Proceedings of the Entomological Society of Washington 87: 751-758.

Wilcove, D. S., D. Rothstein, J. Dubow, A. Phillips, and E. Losos. 1998. Quantifying threats to imperiled species in the United States. BioScience 48: 607-615.

Williamson, M. editor. 1996. Biological invasions. Chapman and Hall, London.

Williamson, M., and A. Fitter. 1996. The varying success of invaders. Ecology 77: 1661-1666.

Wootton, J. T. 1994. The nature and consequences of indirect effects in ecological communities. Annual Review of Ecology and Systematics 25: 443-466.

Zimmermann, H. G., V. C. Moran, and J. H. Hoffman. 1986. Insect herbivores as determinants of the present distribution and abundance of invasive cacti in South Africa. Pages 269-274 in I. A. W. Macdonald, F. J. Kruger, and A. A. Ferrar, editors. Ecology and management of biological invasions in southern Africa. Oxford University Press, Cape Town.

Zwölfer, H., and P. Harris. 1984. Biology and host specificity of Rhinocyllus conicus (Froel.) (Col., Curculionidae), a successful agent for biocontrol of the thistle, Carduus nutans L. Zeitschrift der Angewandte Entomologie 97: 36-62.

Zwölfer, H., K. E. Frick, and L. A. Andres. 1971. A study of the host plant relationships of European members of the genus Larinus (Col.: Curculionidae). Commonwealth Institute of Biological Control Technical Bulletin 14: 97-143. 